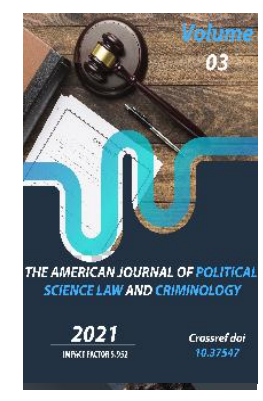

\title{
Innovative Implementation Of Investment Insurance In The Republic Of Uzbekistan
}

\author{
Dauletbike Ametbekovna Eshchanova \\ Lecturer And Independent Researcher For The Department Of Business Law Of Tashkent State \\ University Of Law, Uzbekistan
}

Journal Website:

http://theamericanjour

nals.com/index.php/taj

psic

Copyright: Original

content from this work

may be used under the

terms of the creative

commons attributes

4.0 licence.

\section{ABSTRACT}

This article examines the civil regulation of the innovative implementation of investment insurance activities in the Republic of Uzbekistan, the issues of attracting and using investments through innovative activities. The article provides definitions of the basic concepts of innovation in the field of investment insurance and legal innovation. The analysis of the civil legislation in force in the field of foreign investment insurance regulation and innovative implementation of investment insurance in the country has been carried out. Furthermore, proposals will be made to improve legislation in the field of investment insurance in the republic by introducing IT technologies in the process of investment insurance activities.

\section{KEYWORDS}

Investments, innovations, insurance, civil legislation, legal innovations, investment activities, IT technologies, Fintech, Lawtech.

\section{INTRODUCTION}

The Republic of Uzbekistan has sufficient investment potential. Over the years since gaining state independence, such industries as the automotive industry, agricultural machine building, biotechnology, the pharmaceutical industry, and information technology have been developed. The concept of attracting and using domestic and foreign investments in the country's economy, developed by the government, makes it possible to substantiate the growing trends in the development of the investment process. 
The country has a high demand for investments and innovations, as well as scientific and production potential sufficient for innovative development of investments. This means that there are prerequisites for enhancing innovation in the implementation of investment activities.

International experience shows that innovative technologies are the most important effective means of developing production and forming the economic potential of the state. Namely, innovative technologies include advanced achievements of science and technology, the possibility of introducing scientific and technical developments as well as modernization of production, mastering the release of new products and their subsequent sale in the domestic market.

Local economists pay attentiont to the fact that today most countries of the world set themselves the task of transitioning to an innovative knowledge-based economy, in which the creation, transfer and use of the results of scientific and technical activities are the main conditions for sustainable economic growth. They emphasize that in sovereign Uzbekistan, from the first days of independence, much attention has been paid to the development of domestic science, leading scientific schools and innovative research. [1].

Consequently, in the modern conditions of the development of market relations, attracting and using investments through innovative activities is of primary importance for the Republic of Uzbekistan.
In this aspect, speaking about the legal essence of the concept, innovation legal scholars pay attention to the fact that recently "innovation" and "innovative activity" are the subject of active discussions among politicians, lawyers and businessmen. They believe that that the content of the term "innovation" has not been fully defined. [2].

In accordance with the norms of national legislation, an innovation is a new development introduced into civil practice or used for one's own needs, the application of which in practice ensures the achievement of a significant socio-economic effect. According to the provisions of the legislation, innovative activity is considered as an activity on the creation of new developments, as well as ensuring their transfer and implementation in the production sector (Article 3 of the Law of the Republic of Uzbekistan " On Innovative Activity").

Consequently, the main criterion for innovation and innovative activity is the practical implementation of a new development and obtaining a certain practical results from its implementation.

Definitely, during the process of implementing innovative activities, one should clearly understand what can be considered a new development. In this case, in accordance with Article 3 of the Law of the Republic of Uzbekistan "On Innovative Activity", a new development is the result of intellectual activity (new or improved technology, service and organizational and technical solution of a production, administrative, commercial or other nature), which has signs of novelty compared to existing analogues, practical applicability and the ability to ensure the 
achievement of a significant socio-economic effect when use in practice.

Representatives of local economic science believe that the creation of an effective innovative system using the existing scientific potential, where knowledge is actively used, is one of the primary objectives of the ongoing reforms in the Republic of Uzbekistan. They argue that this is not only about government participation in funding research and implementation, it is more important to create conditions under which the search and support of innovations would be of interest to large and small businesses. Thus, the existing gap between the innovative achievements of local science and their use in production can be overcome.

Unfolding the essence of the concept of legal innovations, it can be considered that innovations are various kinds of borrowings from other legal systems, which are resorted to in order to improve the law, its harmonization. . Innovations are necessary as one of the forms of law renewal. [3]. It is proposed to understand legal innovation as an innovation introduced into the legal system that qualitatively improves its elements in order to harmonize the current law. [3].

From the point of view of modern legal scholars, the peculiarity of innovation, in contrast to other related concepts and categories, such as "novation", "discovery", "improvement", "invention", is that innovations allow both to create and receive, added value and are mainly associated with practical implementation in social practice. [3].

In our opinion, the signs of legal innovation are the following:
First, the introduction of innovations into the legal system of the state;

Secondly, obtaining a specific final innovative results of this implementation.

Thus, the main difference between innovation and other novations can be considered implementation. Scientists mention that implementation is nothing more than the use in practice of any research and experiments. [3]. Representatives of civil law science focus on the fact that no matter what definitions are given in the literature to the concept of "innovation", the main feature is the connection with the creation and implementation of new knowledge, regardless of the scope of its implementation.

Specialists consider the following conditions for successful implementation of innovation:

1) Preliminary preparation of favorable social foundations;

2) Providing effective demonstration support;

3) Active use of examples of successful application of the novelty, taking into account the cognitive capabilities of potential followers. [3].

As a practical example of legal innovation, we can cite, by analogy with Fintech, the sector of creating, testing and introducing financial products using IT technologies into commercial practice, the creation by lawyers of the USA, Great Britain, Canada of Lawtech the field of application of IT technologies in the legal services market. [4].

Specialists define the sphere of legal support of investment activity as one of the directions of introduction of IT technologies into the 
legal business. They refer to this area as the creation of IT integrators independently or in partnership with other legal practices for a single point of legal IT startups, investors and consumers of new software products, the creation and support of the permanent functioning of open IT platforms and permanent IT conferences for the development of commercially attractive and competitive software and hardware solutions for any tasks and problems that clients can apply to legal practice. [4].

Exploring the aspect of the innovative application of investment insurance activities, it is necessary to determine what type of innovation can be attributed to legal innovations in the field of investment insurance activities. According to the investment legislation of our country, innovations are divided into the following types:

Product innovation - aimed at the development and implementation of technically and technologically new or improved products (works and services);

Process innovation - aimed at the development and implementation of technically and technologically new or improved production or educational methods, as well as the implementation of transfer of technologies;

marketing innovation - aimed at introducing new or improved methods, covering changes in the design and packaging of products, the use of new methods of sales and presentation of products (works and services), the formation of new pricing strategies;
Organizational innovation - aimed at introducing new or improved methods of organizing and conducting business, creating jobs and building external relations.

Based on the above types of innovations, it seems possible to consider legal innovation with the use of IT technologies in the field of investment insurance activities as an organizational innovation aimed at improving the methods of conducting an insurance business.

Experts in the field of innovative application, depending on the degree of sustainability, the activity of the implementing entities, their resources and other factors, at the final stage determine whether the innovation will become conceptual or local. They believe that by conceptual innovation should be understood as a fundamental update that increases the complexity of the system. From the standpoint of a synergistic approach, conceptual innovation acts as a factor in the self-organization of fairly large social groups, often opposing each other. During this period of social chaos, there is a branching of the evolutionary path of the social system, a gap in the evolutionary continuity of norms and practices, and subsequently - the "choice" of a specific development trajectory. By local, they mean an innovation that gets limited distribution and does not change the order parameters of the system. It is local in the sense that it has a relatively small number of supporters. An implemented, local or conceptual innovation gradually turns into an active tradition and the circle closes. After the innovation has been implemented in reforms, it begins to be consolidated in the relevant rules, norms, structures and functions of the system. [3]. 
In general, the condition of affairs in the field of innovative application of legal norms, representatives of legal science conclude that a paradoxical situation has developed in jurisprudence, the processes of innovative development are gaining strength, and there is not enough research that forms the necessary groundwork and anticipates legislative innovations. [5].

However, despite this, it can be concluded that the innovative application of investment insurance is regulated mainly by the norms of civil law. This is due to the fact that innovation is an economic activity that contains an intellectual component. From the point of view of M.V. Volynkina the dynamics of innovative activity is due to the use of such civil institutions as objects of civil rights, subjects, contracts and obligations, the institution of intellectual property. Each of these means is designed to create a legal mechanism for the transition of the innovative cycle from one stage to another. [5].

It can be considered that innovations in insurance represent commercial, technical, financial, organizational and social changes in society and the state, which entail the creation of a new insurance product. [6].

Exploring various areas of innovation in the jurisprudence of foreign countries, experts pay attention to the fact that one should not forget about the insurance market and electronic forms of interaction between insurers and their clients in terms of the exchange of claims, protocols of the occurrence of insured events (especially in auto insurance). Foreign scientists emphasize that this is a huge market for lawyers, since disputes in connection with the purchase of insurance policies and the payment of insurance compensation are calculated, for example, in the UK alone in tens of thousands annually. [4].

Representatives of legal science focus on the fact that the economic space is increasingly being filled by such participants, for whom innovation is not an accompanying element of business development, but its goal. They emphasize that currently a completely new trend is being formed in the insurance industry abroad - startups, which in themselves are an innovation of the insurance market. They radically change the idea of the traditional insurance to which everyone is accustomed, since they offer the market completely new products and solutions, distinguished by the originality of the formation of insurance products, their sales and even individual operational processes. [7]. The UK and the USA have become the world leaders in this segment, setting the main trends in the development of the insurance services market, offering, distributing and implementing advanced innovative ideas. [7]. According to the opinion of specialists, the study of their experience is very useful, since on its basis it is quite easy to predict the near future of the insurance market. Taking into account the current trend in the virtualization of legal business, the presence of a large number of software developments and ITmethods for the provision of legal services in foreign countries, the applicant considers it appropriate to propose some measures to further intensify this area of innovative application of investment insurance.

Maintaining the stability of the functioning of insurance companies, especially during periods of crisis and economic instability, 
requires the development of new sales channels for insurance products. The use of the potential information and computer technologies and information networks existing on their basis will be very helpful in expanding the insurance market.

The transfer of most of the insurance operations to the Internet provides potential and real clients of insurance companies with a number of following new opportunities:

- Making, without leaving home, a general idea of the insurance market and the insurer, its services;

- Carrying out an independent calculation of tariffs using an insurance calculator;

- Using online consultations on various insurance issues;

- Assessing the risk in relation to a potential insurance object;

- Submitting an application for the conclusion of an insurance contract in electronic form;

- Concluding an insurance contract and make an insurance premium via the Internet;

- Getting online support for an insurance contract;

- Informing about the occurrence of an insured event via the Internet.

As a practical implementation of IT technologies in the process of investment insurance activities, we propose to create a "virtual insurance office" through which the insurance company selling it will receive the appropriate fees [8].

In the face of insurance companies using the indicated information and computer technologies, the local consumer gets the opportunity to insure himself without leaving his computer. A modern website of an insurance company should provide an opportunity to choose the desired type of insurance, fill out a form to calculate the cost of the insurance policy. You can pay for the purchase of an insurance policy in real time by using plastic cards.

The websites of many insurance companies perform only informational functions, posting on their pages only general data about the company and offered insurance products, sometimes a description of their activities. For these reasons, many sites of foreign insurers cannot be considered full-fledged Internet representations. Not many insurance companies get to create a full-fledged virtual office. However, step by step, foreign insurance companies are expanding the range of services of their Internet representations.

Scientific analysis of the current affairs in the field of innovative application of investment insurance activities allows us to make the following conclusions:

1) The preliminary conditions for innovative activities in investment insurance are the following:

Features of investment insurance as a separate type of insurance;

The desire of foreign insurers to make investment insurance more affordable through the use of information technology;

The passivity of the majority of local insurers in the application of information technologies.

2) The need for innovation in insurance is determined by the development of new 
information technologies, increased competition not so much on the part of local insurers, but also on the part of foreign participants in the insurance market.

Thus, in the process of studying the innovative aspect of the development of investments, one can come to the conclusion that it is necessary to create a more effective regulatory and legislative framework, as well as organizational, economic, financial, tax infrastructure, material, technical and informational conditions in this area that are adequate to modern requirements, to conduct a more flexible personnel policy in order to ensure the implementation of state significant innovation priorities.

\section{REFERENCES}

1. https://cyberleninka.ru/article/n/sovers henstvovanie-infrastrukturyinnovatsionnoy-deyatelnosti-vuzbekistane-sostoyanie-problemy-iperspektivy/.

2. Gerkushenko M.A. The legal nature of innovations in the civil legislation of the Russian Federation. Page 1.

3. Kuryshev E.Yu. Innovations as a form of legal renewal // Actual problems of law: materials of a scientific Conference. Publisher: Buki-Vedi, (2015) Pages 9,12

4. https://zakon.ru/blog/2017/12/16/innova cii_v_yurisprudencii_obzor_dostizheni j_i_tendencij_v_oblastiittehnologizacii_yuridicheskogo_b_7182 8.

5. Volynkina M.V. Civil legal form of innovative activity // Autobiography.
Candidate for Juris Doctor. Publisher: Nauk. (2007). Page 13.

6. Savvina N.G. Innovations in Russian insurance fashion or necessity // Bulletin of the Financial University: Moscow: No. 6. (2014). Page 75.

7. Stepanova N.M. Insurance innovations main world trends. Page 342.

8. Dauletbike Eshchanova. Actual problems of legislation of the development of internet insurance in Uzbekistan. TSUL Legal Report International electronic scientific journal 1 (1). (2020). E-ISSN: 2181-1024. Pages $69-72$.

9. Lutfullaevich, Y. G. (2020). Impact of inflation on R\&D investment flow: Case of five Countries. International Journal of Scientific and Technology Research, 9(1), 1970-1974.

10. Yoziev, G. L. (2021). Conceptual approaches to building a perspective model of national innovation systems: Lessons for Uzbekistan. South Asian Journal of Marketing \& Management Research, 11(3), 46-52. 